\title{
PENGEMBANGAN MODUL BERBASIS EXPERIENTIAL LEARNING PADA MATAKULIAH PERENCANAAN PEMBELAJARAN AKUNTANSI
}

\author{
Effi Aswita Lubis ${ }^{1}$, Efendi Napitupulu', Eko Wahyu Nugrahadi ${ }^{3}$ \\ ${ }_{1,3}^{3}$ Pendidikan Akuntansi, Fakultas Ekonomi, Universitas Negeri Medan \\ ${ }_{2}^{2}$ Pendidikan Teknik Bangunan, Fakultas Teknik, Universitas Negeri Medan \\ effiaswitalubis@gmail.com³
}

\begin{abstract}
Abstrak: Penelitian ini bertujuan: (1) mengetahui kelayakan modul berbasis Experiential Learning pada matakuliah Perencanaan Pembelajaran Akuntansi; (2) mengetahui keefektifan modul berbasis Experiential Learning matakuliah Perencanaan Pembelajaran Akuntansi. Hasil penelitian menunjukkan: Kualitas pelaksanaan pembelajaran pada uji coba terbatas sangat baik dan layak digunakan dalam proses pembelajaran perencanaan pembelajaran akuntansi. Penilaian mahasiswa terhadap Pelaksanaan Pembelajaran menggunakan modul melalui Uji Coba Terbatas layak digunakan dalam proses perencanaan pembelajaran akuntansi. Rata-rata hasil belajar perencanaan pembelajaran pendidikan akuntasi mahasiswa menunjukkan bahwa ada perbedaan yang signifikasi, bahwa yang dibelajarkan dengan menggunakan modul Pembelajaran berbasis Eksperimen Kolb Berbasis lebih tinggi pada hasil pretes, postes dari pada dengan konvensional. Hal ini menunjukkan bahwa model pembelajaran yang dikembangkan mampu meningkatkan hasil belajar mahasiswa dalam pembelajaran perencanaan pembelajaran akuntansi.
\end{abstract}

Kata Kunci: modul, experiential learning, perencanaan pembelajaran akuntansi

Abstract: This study aims: (1) to determine the feasibility of a module based on Experiential Learning in Accounting Learning Planning subject; (2) to determine the effectiveness of the Experiential Learning-based module in the Accounting Learning Planning course. The results showed: The quality of the implementation of learning in limited trials is very good and feasible to be used in the learning process of accounting learning planning. Student assessment of the Learning Implementation using modules through Limited Trials is feasible to be used in the accounting learning planning process. The average learning outcomes of students' accounting education learning planning shows that there are significant differences, that what is learned using the Kolb Experiment-based Learning module is higher in the results of the pretest, posttest than conventional. This shows that the learning model developed is able to improve student learning outcomes in accounting learning planning.

Keywords: modules, experiential learning, accounting learning planning

\section{PENDAHULUAN}

Perencanaan Pembelajaran Akuntansi di berbagai perguruan tinggi saat ini dituntut untuk memiliki kemampuan dalam pemahaman akuntansi. Berkembangnya teknologi sekarang ini seperti internet, komputerisasi dan sebagainya sangat memudahkan seorang mahasiswa dalam mengembangkan ilmu pengetahuannya. Namun, teknologi yang semakin berkembang tersebut bukanlah jaminan bagi pendidikan untuk berhasil dan mencapai hasil yang maksimal. Salah satu faktor yang dapat mendukung keberhasilan program studi akuntansi adalah sikap dan mental mahasiswa dalam mengembangkan kepribadiannya dan dituntut untuk kemampuan dalam pemahaman ilmu akuntansi sehingga, memilki nilai tambah dalam persaingan dunia kerja.

$$
\text { Dalam upaya mengembangkan }
$$

Perencanaan Pembelajaran Akuntansi yang berlandaskan profesionalisme, dibutuhkan adanya umpan balik mengenai kondisi yang ada sekarang, yaitu apakah Perencanaan Pembelajaran Akuntansi di Indonesia telah cukup membentuk nilai-nilai positif mahasiswa akuntansi. Sebagai wujud pemahaman mahasiswa akuntansi, profesionalisme dan nilai positif teori akuntansi sebenarnya merupakan cerminan pemahaman konsep dasar akuntansi para mahasiswa. Namun menurut Novius (2010) dinyatakan bahawa, Perencanaan Pembelajaran Akuntansi yang selama ini diajarkan di perguruan tinggi hanya terkesan sebagai pengetahuan yang berorientasi pada mekanisme secara umum saja, sangat berbeda apabila dibandingkan dengan praktik yang sesungguhnya yang dihadapi didunia kerja nantinya.

Tingkat pemahaman akuntansi mahasiswa dinyatakan dengan seberapa 
mengerti seorang mahasiswa terhadap apa yang sudah dipelajari yang dalam konteks ini mengacu pada mata kuliah akuntansi dan Indeks Prestasi Komulatif (IPK). Tanda seorang mahasiswa memahami akuntansi tidak hanya ditujukan dari nilai-nilai yang didapatkannya dalam mata kuliah tetapi juga apabila mahasiswa tersebut mengerti dan dapat menguasai konsep-konsep yang terkait. Menurut Munawir (2004) menyatakan bahwa Ada tiga materi pokok tentang konsep dasar akuntansi yang harus dikuasai oleh mahasiswa akuntansi dalam kuliah Akuntansi Pengantar, yaitu pemahaman tentang aktiva, kewajiban dan modal. Dari ketiga materi tersebut diharapkan dapat mengikuti perkuliahan dengan baik dan benar karena dengan penguasaan yang baik terhadap aktiva, kewajiban dan modal akanmempermudah mahasiswa untuk memahami masalah-masalah yang akan ditemui dalam akuntansi.

\section{Pendidikan Akuntansi}

Menurut Depdiknas (2003: 6), akuntansi merupakan bahan kajian mengenai suatu sistem untuk menghasilkan informasi berkenaan dengan transaksi keuangan. Informasi tersebut dapat digunakan dalam rangka pengambilan keputusan dan tanggungjawab di bidang keuangan baik oleh pelaku ekonomi swasta (akuntansi perusahaan), pemerintah (akuntansi pemerintah), ataupun organisasi masyarakat lainnya (akuntansi publik). Pembelajaran merupakan kegiatan yang dilakukan untuk menciptakan suasana atau memberikan pelayanan agar mahasiswa belajar, pembelajaran lebih menekankan pada guru dalam upayanya untuk membuat mahasiswa dapat belajar tidak hanya membuat adanya perubahan tingkah laku mahasiswa (Sardiman, 2011: 20-21). Dapat disimpulkan pembelajaran akuntansi adalah proses membuat orang belajar atau rangkaian kejadian yang mempengaruhi mahasiswa sehingga proses belajarnya dapat berlangsung mudah untuk menyampaikan sekumpulan materi modul berdasarkan landasan keilmuan akuntansi yang akan dibelajarkan kepada peserta didik sebagai beban belajar melalui metode dan pendekatan tertentu.

\section{Perencanaan Pembelajaran Akuntansi}

Perencanaan menurut William $\mathrm{H}$. Newman dalam bukunya Administrative Action Technigues of Organization and Management mengemukakan bahwa "perencanaan adalah menentukan apa yang akan dilakukan (dalam Majid, 2006). Lebih lanjut, perencanaan berisi rangkaian putusan yang luas dan penjelasanpenjelasan tentang tujuan, penentuan kebijakan, penentuan program, penentuan metode-metode dan prosedur tertentu dan penentuan kegiatan berdasarkan jadwal seharihari”. Terry (dalam Majid, 2006) menyatakan bahwa perencanaan adalah menetapkan pekerjaan yang harus dilaksanakan oleh kelompok untuk mencapai tujuan yang digariskan. Mengingat perencanaan berisi kegiatan pengambilan keputusan, diperlukan kemampuan untuk mengadakan visualisasi dan melihat ke depan guna merumuskan suatu pola tindakan untuk masa depan.

\section{Model Pembelajaran}

Model menurut Joyce, Weil, \& Calhoun (2000: 13-28) dikelompokkan menjadi empat keluarga, yaitu: (1) model pemrosesan informasi (information processing family model), (2) model pribadi (personal family model), (3) model interaksi sosial (social family model), dan model perilaku (behavioral system family model). Menurut Joyce, Weil, \& Calhoun (2000: 135), semua model mengajar mengandung unsur model berikut: (1) orientasi model, yaitu fokus atau kerangka acuan yang menyangkut tujuan pengajaran dan aspek lingkungan; (2) urutan kegiatan (syntax), yaitu tahapan tindakan model; (3) sistem sosial (social system), yakni norma (sikap, keterampilan, pengertian) yang menyangkut hubungan antara guru dan mahasiswa , (4) prinsip reaksi (principle of reaction); (5) sistem penunjang (support system), yakni instrumen pendukung terhadap keberhasilan guru dan mahasiswa seperti teks, OHP; dan (6) dampak instruksional dan penyerta (instructional and nurturant effect).

Menurut Muhammad (2015:29) model pembelajaran adalah kerangka konseptual yang mendeskripsikan dan melukiskan prosedur yang sistematik dalam meng-organisasikan pengalaman belajar dan pembelajaran untuk mencapai tujuan belajar tertentu dan berfungsi sebagai pedoman dalam perencanaan bagi pendidik dalam perencanaan pembelajaran bagi para pendidik dalam melaksanakan aktivitas pembelajaran.

Menurut Andi (2015:239) model pembelajaran adalah suatu rencana atau pola yang dapat digunakan untuk membentuk 
kurikulum dan pembelajaran jangka panjang, merancang bahan-bahan pembelajaran, dan membimbing pembelajaran di kelas atau di luar kelas. Model pembelajaran dapat dijadikan sebagai pola pilihan, artinya guru boleh memilih model pembelajaran yang sesuai dan efisien untuk mencapai tujuan pembelajaran.

\section{Model Pemebelajaran Experiential Kolb}

Pada tahun 1984, David A. Kolb, menerbitkan buku terobosan berjudul Experiential Learning: pengalaman sebagai sumber pembelajaran dan pengembangan (Englewood Cliffs, Prentice Hall, 1984). Buku ini pada dasarnya mengungkap prinsip bahwa seseorang akan belajar melalui penemuan dan pengalaman. Alasan teori ini disebut "pengalaman" adalah asal-usul intelektualnya diambil dari karya eksperimental dari Lewin, Piaget, Dewey, Freire dan James, membentuk perspektif unik tentang pembelajaran dan pengembangan.

Model pembelajaran Experiential Kolb (Manolas, 2005). Model pembelajaran ini menyajikan empat tahapan yaitu tahap pertama pengalaman kongkrit (concrete experience) bagi mahasiswa sebagai awal pembelajaran. Pada tahap ini mahasiswa secara individu menekankan pada pembelajaran berpikir terbuka dan kemampuan beradaftasi daripada pendekatan sistematik pada situasi masalah. Tahap kedua yaitu pengamatan reflektif (reflective observation). Pada tahap ini mahasiswa mengamati demonstrasi sederhana serta mencoba mengeluarkan pendapat mengapa dan bagaimana hal tersebut terjadi. Tahap ketiga yaitu konsepsi abstrak (abstrak conceptualization). Pada tahap ini menjadi mengerti konsep secara umum dengan tahap pertama dan kedua sebagai acuan. Konsepsi abstrak mengharuskan mahasiswa untuk menggunakan logika dan pikiran untuk memahami situasi dan masalah. Kemudian tahap keempat diselesaikan melalui percobaan aktif (active experimentation). Pada tahap ini mahasiswa menggunakan teori yang mereka dapat selama konsepsi abstrak untuk membuat prediksi. Melalui pembelajaran ini diharapkan dapat membangun konsep yang bermakna dan kepercayaan diri dalam memecahkan masalah dan membuat keputusan yang cermat.

Kolb (dalam Muhammad, 2015:128) mengemukakan bahwa model pembelajaran experiential adalah belajar sebagai proses mengkontruksi pengetahuan melalui transformasi pengalaman. Belajar dari pengalaman mencakup keterkaitan antara berbuat dan berpikir. Jika seseorang berbuat aktif maka orang itu akan belajar jauh lebih baik. Hal ini disebabkan dalam proses belajar tersebut pembelajar secara aktif berpikir tentang apa yang dipelajari dan kemudian bagaimana menerapkan apa yang telah dipelajari dalam situasi nyata.

Berdasarkan latar belakang masalah, maka penelitian ini dapat dirumuskan sebagai berikut: (1) Bagaimanakan mengembangkan modul pembelajaran berbasis experiential learning pada Perencanaan Pembelajaran akuntansi; (2) Apakah modul pembelajaran berbasis experiential learning yang dikembangkan layak digunakan pada Perencanaan Pembelajaran akuntansi; (3) Apakah modul pembelajaran berbasis experiential learning yang dikembangkan efektif digunakan pada Perencanaan Pembelajaran akuntansi; dan (4) Apakah terdapat peningkatan hasil belajar mahasiswa yang diajarkan dengan menggunakan modul pembelajaran berbasis experiential learning dengan menggunakan modul pembelajaran berbasis experiential learning Perencanaan Pembelajaran akuntansi.

\section{METODE}

Penelitian ini merupakan penelitian dan pengembangan (Research \& Development), Penelitian dan pengembangan ini terdiri dari tiga tahap yaitu pra pengembangan model, pengembangan model dan penerapan model dimana penelitian mengacu pada $R \& D$. Penelitian ini menggunakan metode $R \& D$ (Research and Development) dalam prosesnya. Peneliti menggunakan model 4D (DefineDesign-Develop-Disseminate) sebagai jenis pengembangan modul yaitu buku ajar. Jenis pengembangan 4D dikembangkan oleh Thiagarajan, Semmel dan Semmel (Trianto, 2014).

Penelitian dilakukan di Program Studi Pendidikan Akuntansi, FE UNIMED pada matakuliah Perencanaan Pembelajaran Akuntansi Tahun Akademik 2020/2021. Baik validasi ahli, uji coba perorangan, ujicoba kelompok kecil, dan ujicoba utama dilakukan di Unimed. Subjek penelitian adalah mahasiswa dan dosen. Pada tahap pengembangan model pembelajaran, penentuan sasaran dalam hal ini adalah dosen, pakar pembelajaran, ahli bidang studi, dan mahasiswa yang menilai modul 
pembelajaran yang telah dikembangkan berdasarkan kriteria, sebagai berikut: (1) evaluasi pakar pembelajaran (expert judgement) ditentukan berdasarkan kepakaran yang dimilikinya, (2) evaluator yang melaksanakan evaluasi ditentukan berdasarkan pada kemampuan dosen dengan klasifikasi ahli bidang studi.

Penelitian dilakukan di Program Studi Pendidikan Akuntansi pada matakuliah Perencanaan Pembelajaran Akuntansi di semester 3 (Ganjil). Baik uji coba perorangan, ujicoba kelompok kecil, dan ujicoba utama dilakukan di Unimed. Pada tahap pengembangan model pembelajaran, penentuan sasaran dalam hal ini adalah dosen, pakar pembelajaran, ahli bidang studi, dan mahasiswa yang menilai model pembelajaran yang telah dikembangkan berdasarkan kriteria, sebagai berikut: (1) evaluasi pakar pembelajaran (expert judgement) ditentukan berdasarkan kepakaran yang dimilikinya, (2) evaluator yang melaksanakan evaluasi ditentukan berdasarkan pada kemampuan dosen dengan klasifikasi ahli bidang studi.

Uji validitas digunakan untuk mengukur kebenaran suatu tes agar dapat dipertanggungjawabkan untuk mencapai kompetensi yang diharapkan. Uji validitas dapat diukur dengan menggunakan rumus berikut ini (Sudijono, 2011: 185).

$$
r_{\text {pbis }}=\frac{M p-M t}{S D_{t}} \sqrt{\frac{p}{q}}
$$

Keterangan:

$\mathrm{r}_{\mathrm{pbis}}$ : Validitas tes

$\mathrm{M}_{\mathrm{p}}$ : Skor rata-rata mahasiswa yang menjawab item dengan benar

$\mathrm{M}_{\mathrm{t}}$ : Skor rata-rata dari skor total

$\mathrm{SD}_{\mathrm{t}}$ : Standar deviasi dari skor total

$\mathrm{p}$ : Proporsi mahasiswa menjawab benar

q : Proporsi mahasiswa menjawab salah

Setelah hasil diperoleh, maka

suatu soal dikatakan valid jika $r_{\text {hitung }}>r_{\text {tabel }}$. Sedangkan soal dinyatakan tidak valid jika $r_{\text {hitung }}<r_{\text {tabel. }}$.

\section{Reliabilitas Tes}

Uji reliabilitas digunakan untuk menilai ketelitian, ketepatan, dan konsistensi suatu tes untuk digunakan dalam jangka waktu tertentu. Reliabilitas dari tes yang diberikan dapat diuji dengan rumus berikut ini (Sudijono, 2011: 254).

$$
\mathrm{r}_{\mathrm{ii}}=\left(\frac{\mathrm{n}}{(\mathrm{n}-1)}\right)\left(\frac{\mathrm{SD}_{\mathrm{t}}^{2}-\sum \mathrm{pq}}{\mathrm{SD}_{\mathrm{t}}^{2}}\right)
$$

Keterangan:

$\mathrm{r}_{\mathrm{ii}} \quad$ : reliabilitas

p : proporsi peserta tes menjawab benar

q : proporsi peserta tes menjawab salah

$\sum \mathrm{pq}$ : jumlah hasil perkalian antara $\mathrm{p}$ dengan $\mathrm{q}$

n : banyak soal

$\mathrm{SDt}^{2}$ : Standar deviasi atau simpangan baku

Suatu tes dapat dikatakan reliabel jika rii lebih besar atau sama dengan 0,70 dan tidak lebih besar daripada 1,00 atau dapat dilambangkan dengan $0,70 \leq$ rii $\leq 1,00$. Jika ternyata tes dinyatakan tidak reliabel, maka perangkat soal harus diganti.

\section{Tingkat Kesukaran Tes}

Pengujian tingkat kesukaran tes menggunakan rumus Robert L. Thorndike (dalam Sudijono, 2011: 372) sebagai berikut.

$$
\mathrm{P}_{\mathrm{n}}=\frac{\mathrm{B}_{\mathrm{n}}}{\mathrm{J}_{\mathrm{s}}}
$$

Keterangan: $\mathrm{Pn}=$ Tingkat kesukaran item ke-n

$\mathrm{Bn}$ = Banyak mahasiswa menjawa benar item ke-n

Js = Jumlah seluruh mahasiswa

Soal kemudian dapat dikategorikan tingkat kesukarannya dengan melihat tabel di bawah ini.

Tabel 1. Kategori Tingkat Kesukaran Tes

\begin{tabular}{|c|c|}
\hline Nilai & Kriteria \\
\hline $0,00<\mathrm{P}<0,30$ & Sukar \\
\hline $0,30<\mathrm{P}<0,70$ & Sedang \\
\hline $0,70<\mathrm{P}<1,00$ & Mudah \\
\hline
\end{tabular}

\section{Analisis Kelayakan Produk}

Teknik analisis data yang digunakan dalam penelitian ini yaitu teknik analisis deskriptif kuantitatif. Angket akan dibagi ke dalam 5 jenis pernyataan kemudian dikonveksikan ke dalam bentuk angka sebagai berikut.

Tabel 2. Pedoman Pemberian Skor

\begin{tabular}{|c|c|}
\hline Keterangan & Skor \\
\hline SS (Sangat Setuju) & 5 \\
\hline S (Setuju) & 4 \\
\hline R (Ragu-ragu) & 3 \\
\hline TS (Tidak Setuju) & 2 \\
\hline
\end{tabular}




\section{STS (Sangat Tidak Setuju)}

Skor yang telah diperoleh kemudian dijumlah untuk memperoleh rata-ratanya. Rumus yang digunakan untuk mencari rata-rata skor sesuai dengan Sudjana (2005:66) sebagai berikut:

$$
\overline{\mathrm{x}}=\frac{\sum \mathrm{Xi}}{\mathrm{n}}
$$

Keterangan:

$\overline{\mathrm{X}} \quad$ = skor rata-rata

$\sum \mathrm{xi} \quad=$ jumlah skor

$\mathrm{n} \quad=$ jumlah soal

Setelah skor rata-rata diperoleh, maka kemudian pemberian kategori secara kualitatif disesuaikan dengan rumus Widoyoko (2010: 238).

Tabel 3. Konversi Data Kuantitatif ke Data Kualitatif Berskala 5

\begin{tabular}{|c|c|c|c|}
\hline No. & Rentang skor & $\begin{array}{c}\text { Rentang } \\
\text { skor }\end{array}$ & Kategori \\
\hline 1. & $\mathrm{X}>\mathrm{Mi}+1,8 \mathrm{SBi}$ & $\mathrm{X}>4,2$ & $\begin{array}{c}\text { Sangat } \\
\text { Baik }\end{array}$ \\
\hline 2. & $\mathrm{Mi}+0,6 \mathrm{Sbi}<\mathrm{X} \leq$ & $3,4<\mathrm{X}$ & Baik \\
$\mathrm{Mi}+1,8 \mathrm{SBi}$ & $\leq 4,2$ & \\
\hline 3. & $\mathrm{Mi}-0,6 \mathrm{Sbi}<\mathrm{X} \leq$ & $2,6<\mathrm{X}$ & Cukup \\
& $\mathrm{Mi}+0,6 \mathrm{SBi}$ & $\leq 3,4$ & \\
\hline & $\mathrm{Ii}-1,8 \mathrm{Sbi}<\mathrm{X} \leq \mathrm{Mi}$ & $\begin{array}{c}1,8<\mathrm{X} \\
\leq 2,6\end{array}$ & Kurang \\
\hline & $\mathrm{X} \leq \mathrm{Mi}-1,8 \mathrm{SBi}$ & $\mathrm{X} \leq 1,8$ & $\begin{array}{c}\text { Sangat } \\
\text { Kurang }\end{array}$ \\
\hline
\end{tabular}

Keterangan:

$\mathrm{X}=$ skor aktual (skor yang dicapai)

$\mathrm{Mi} \quad=$ rerata ideal

$=(1 / 2)$ (skor tertinggi ideal + skor

terendah ideal)

$\mathrm{SBi}=$ simpangan baku ideal

$=(1 / 6)$ (skor tertinggi ideal - skor terendah ideal)

Berdasarkan tabel 3.5, maka produk pengembangan media dapat dikategorikan sesuai dengan penilaian berikut.

Tabel 4.1 Kategorisasi Produk

\begin{tabular}{|c|c|c|c|}
\hline No. & Interval Skor & Nilai & Kategori \\
\hline 1. & $\mathrm{X}>4.2$ & $\mathrm{~A}$ & Sangat baik \\
\hline 2. & $3,4<\mathrm{X} \leq 4,2$ & $\mathrm{~B}$ & Baik \\
\hline 3. & $2,6<\mathrm{X} \leq 3,4$ & $\mathrm{C}$ & Cukup \\
\hline 4. & $1,8<\mathrm{X} \leq 2,6$ & $\mathrm{D}$ & Kurang \\
\hline 5. & $\mathrm{X} \leq 1,8$ & $\mathrm{E}$ & Sangat \\
\hline
\end{tabular}

Kriteria kelayakan produk mengacu pada pendapat Sukardjo seperti yang dikutip dari Miyarso (2009: 69-70) bahwa suatu produk yang dikembangkan dapat dikatakan sudah layak digunakan sebagai media pembelajaran apabila hasil penilaian dari ahli materi, ahli media, guru, dan mahasiswa memperoleh nilai termasuk dalam kriteria baik.

\section{Analisis Keefektifan Produk}

Analisis data dalam menguji keefektifan produk menggunakan analisis statistik. Untuk menganalisis perbedaan nilai pretes dan posttes kedua kelas digunakan uji $\mathrm{t}$ sampel (one sample $t$ test). Analisis data dilakukan dengan menggunakan aplikasi SPSS dengan pertimbangan agar data yang diberikan lebih tajam dan akurat.

Sebelum melakukan uji t, data dipastikan bersifat homogen dan berdistribusi normal. Untuk menguji normalitas, data yang diperoleh sesuai dengan hasil uji Shapiro dan Liliefors dalam SPSS. Data dikatakan normal jika hasil statistik menunjukkan angka $>0,05$. Sedangkan untuk menguji homogenitas, data diambil berdasarkan metode Levene's Test. Jika nilai yang diperoleh $>0,05$ maka data dikatakan homogen.

Setelah diadakan uji normalitas dan homogenitas, maka nilai tes kedua kelas diuji dengan SPSS. Jika nilai signifikansi $<0,05$ berarti Ho ditolak (ada perbedaan yang signifikan antara nilai pretes dengan nilai postes) (Saragih, 2015:189).

Hasil yang telah diperolah dari uji $t$ sampel kemudian digunakan untuk mengetahui peningkatan pemahaman mahasiswa dengan menggunakan teknik analisis data gain-test dalam menghitung nilai gain $(g)$.

$$
g=\frac{\text { skor postes }- \text { skor pretes }}{\text { skor ideal }- \text { skor pretes }}
$$

(Sumber: Herlanti, 2014:74)

Nilai gain yang telah diperoleh kemudian dikategorikan sesuai dengan penilaian pada tabel berikut (Jumiati, dkk., 2011:170) .

Tabel 5. Kriteria Nilai Gain

\begin{tabular}{|c|c|}
\hline Nilai $\mathrm{g}$ & Kriteria \\
\hline $\mathrm{g}>0,7$ & Tinggi \\
\hline $0,7 \geq \mathrm{g}>0,3$ & Sedang \\
\hline $\mathrm{g} \leq 0,3$ & Rendah \\
\hline
\end{tabular}

Peningkatan pemahaman mahasiswa dikategorikan tinggi jika nilai gain yang 
diperoleh lebih dari 0,7, dikategorikan sedang jika nilai gain di antara 0,7 dan tidak sampai pada nilai 0,3 . Jika nilai yang diperoleh adalah 0,3 atau lebih sedikit, maka peningkatan pemahaman mahasiswa dikategorikan rendah.

\section{HASIL PENELITIAN}

Modul Perencanaan Pembelajaran Akuntansi ini dilakukan validasi terlebih dahulu oleh dua orang pakar/ahli bidang studi. Setiap ahli/pakar diminta untuk menilai kelayakan modul Perencanaan Pembelajaran Akuntansi yang dikembangkan, sehingga dapat diketahui kelemahan dan kekuatannya. Validasi modul Perencanaan Pembelajaran Akuntansi ini setelah dilakukan penilaian terhadap komponen kelayakan, selanjutnya dilakukan revisi/perbaikan. Hasil dari revisian/perbaikan modul dikembangkan lagi untuk dijadikan modul yang siap digunakan oleh mahasiswa dalam proses pembelajaran. Modul Perencanaan Pembelajaran Akuntansi yang dikembangkan ini diorganisir terhadap penataan isi materi modul, sehingga dapat memudahkan mahasiswa belajar.

Tabel 6. Penilaian Ahli Media Pembelajaran pada Modul Perencanaan Pembelajaran Akuntansi

\begin{tabular}{|c|c|c|c|}
\hline No. & Indikator & $\%$ & Kriteria \\
\hline \multirow[t]{3}{*}{1.} & Ukuran Modul & & \\
\hline & a. Kesesuaian ukuran modul dengan standar ISO & 80.5 & SB \\
\hline & b. Kesesuaian ukuran dengan materi isi modul & 88.5 & SB \\
\hline \multirow[t]{10}{*}{2.} & Desain Sampul Modul (Cover) & & \\
\hline & $\begin{array}{l}\text { a. Penampilan unsur tata letak pada sampul muka, belakang dan } \\
\text { punggung secara harmonis memiliki irama dan kesatuan (unity) serta } \\
\text { konsisten }\end{array}$ & 80.5 & B \\
\hline & b. Menampilkan pusat pandang (center point) yang baik. & 87.0 & $\mathrm{~B}$ \\
\hline & $\begin{array}{l}\text { c. Komposisi dan ukuran unsur tata letak (judul, pengarang, ilustrasi, } \\
\text { logo, dll) proporsional, seimbang dan seirama dengan tata letak isi } \\
\text { (sesuai pola). }\end{array}$ & 80.5 & \\
\hline & d. Warna unsur tata letak harmonis dan memperjelas fungsi & 88.5 & $\mathrm{~B}$ \\
\hline & $\begin{array}{l}\text { e. Ukuran huruf judul buku lebih dominan dan proporsional dibandingkan } \\
\text { ukuran buku, nama pengarang }\end{array}$ & 84.5 & \\
\hline & f. Warna judul buku kontras dengan warna latar belakang & 80.0 & SB \\
\hline & g. Tidak menggunakan terlalu banyak kombinasi jenis huruf & & SB \\
\hline & h. Menggambarkan isi/ materi ajar dan mengungkapkan karakter objek & 80.5 & SB \\
\hline & i. Bentuk, warna, ukuran, proporsi obyek sesuai dengan realita. & 80.0 & SB \\
\hline \multirow[t]{18}{*}{3.} & Desain Isi Modul: & & \\
\hline & a. Penempatan unsur tata letak konsisten berdasarkan pola & 80.5 & SB \\
\hline & b. Pemisahan antar paragraf jelas & 88.5 & SB \\
\hline & c. Bidang cetak dan margin proporsional & 78.5 & $\mathrm{~B}$ \\
\hline & d. Marjin dua halaman yang berdampingan proporsional & 80.5 & SB \\
\hline & e. Spasi antara teks dan ilustrasi sesuai & 87.0 & SB \\
\hline & $\begin{array}{l}\text { f. Penempatan judul kegiatan belajar, sub judul kegiatan belajar, dan } \\
\text { angka halaman/ folio tidak mengganggu pemahaman }\end{array}$ & 84.5 & SB \\
\hline & $\begin{array}{l}\text { g. Penempatan ilustrasi dan keterangan gambar (caption) tidak } \\
\text { mengganggu pemahaman }\end{array}$ & 80.0 & B \\
\hline & $\begin{array}{l}\text { h. Penempatan hiasan/ ilustrasi sebagai latar belakang tidak mengganggu } \\
\text { judul, teks, angka halaman }\end{array}$ & 80.5 & B \\
\hline & $\begin{array}{l}\text { i. Penempatan judul, subjudul, ilustrasi, dan keterangan gambar tidak } \\
\text { mengganggu pemahaman }\end{array}$ & 80.5 & SB \\
\hline & j. Tidak menggunakan terlalu banyak jenis huruf & 84.5 & B \\
\hline & $\begin{array}{l}\text { k. Penggunaan variasi huruf (bold, italic, all capital, small capital) tidak } \\
\text { berlebihan }\end{array}$ & 80.0 & SB \\
\hline & 1. Lebar susunan teks normal & 80.5 & $\mathrm{~B}$ \\
\hline & m. Spasi antar baris susunan teks normal & 80.5 & SB \\
\hline & n. Spasi antar huruf (kerning) normal & 86.5 & SB \\
\hline & o. Jenjang/ hierarki judul-judul jelas, konsisten dan proporsional & 82.5 & SB \\
\hline & p. Tanda pemotongan kata (hyphenation) & 84.5 & $\mathrm{~B}$ \\
\hline & q. Ilustrasi isi mampu mengungkap makna/ arti dari objek & 80.0 & SB \\
\hline
\end{tabular}




\begin{tabular}{|l|l|c|c|}
\hline No. & \multicolumn{1}{|c|}{ Indikator } & $\%$ & Kriteria \\
\hline & r. Bentuk akurat dan proporsional sesuai dengan kenyataan & 80.5 & B \\
\hline & s. Ilustrasi isi penyajian keseluruhan serasi & 80.5 & B \\
\hline & t. Kreatif dan dinamis ilustrasi isi & 88.5 & B \\
\hline
\end{tabular}

Keterangan: $\mathrm{B}=$ Baik dan $\mathrm{SB}=$ Sangat Baik

Tabel 7. Penilaian Ahli Materi Pembelajaran pada Modul Perencanaan Pembelajaran Akuntansi

\begin{tabular}{|c|c|c|c|}
\hline No. & Indikator & $\%$ & Kriteria \\
\hline \multirow[t]{17}{*}{1} & Aspek Kelayakan Isi: & & \\
\hline & a. Kelengkapan materi sesuai Capaian Pembelajaran & 84.5 & SB \\
\hline & b. Keluasan materi & 80.0 & \\
\hline & c. Kedalaman materi & & $\mathrm{B}$ \\
\hline & d. Keakuratan konsep dan definisi & 80.5 & B \\
\hline & e. Keakuratan data dan fakta & 88.5 & SB \\
\hline & f. Keakuratan contoh dan kasus & 85.0 & SB \\
\hline & g. Keakuratan gambar, diagram, dan ilustrasi & 84.5 & SB \\
\hline & h. Keakuratan istilah-istilah & 84.5 & SB \\
\hline & i. Keakuratan notasi, simbol, dan ikon & 80.0 & SB \\
\hline & j. $\quad$ Keakuratan acuan pustaka & 80.5 & SB \\
\hline & k. Kesesuaian materi dengan perkembangan & 85.0 & SB \\
\hline & 1. Contoh dan kasus dalam dalam penggunakan & 80.5 & \\
\hline & m. Gambar, diagram dan ilustrasi & 84.5 & $\mathrm{~B}$ \\
\hline & n. Kemutahiran pustaka & 80.0 & B \\
\hline & o. Mendorong rasa ingin tahu & 80.5 & SB \\
\hline & p. Menciptakan kemampuan bertanya tentang & 80.5 & SB \\
\hline \multirow[t]{12}{*}{2} & Aspek Penyajian: & 75.5 & $\mathrm{~B}$ \\
\hline & a. Konsistensi sistematika sajian dalam kegiatan belajar & 84.5 & SB \\
\hline & b. Keruntutan konsep penyajiannya & 84.5 & SB \\
\hline & $\begin{array}{l}\text { c. Contoh-contoh soal dalam setiap kegiatan belajar mendukung } \\
\text { penyajian }\end{array}$ & 80.0 & B \\
\hline & d. Soal latihan pada setiap akhir kegiatan belajar & 80.5 & $\mathrm{~B}$ \\
\hline & e. Kunci jawaban soal latihan & 80.5 & $\mathrm{~B}$ \\
\hline & f. Pengantar glosarium & 80.5 & SB \\
\hline & g. Daftar pustaka & 75.5 & $\mathrm{~B}$ \\
\hline & h. Rangkuman & 84.5 & SB \\
\hline & i. Keterlibatan mahasiswa dalam penyajian pembelajaran & 80.0 & SB \\
\hline & j. Ketertautan antar kegiatan belajar/sub kegiatan & 80.5 & SB \\
\hline & k. belajar/alenia secara runtut alur pikirnya & 80.5 & SB \\
\hline \multirow[t]{7}{*}{3} & Penilaian Bahasa: & & \\
\hline & a. Lugas & 80.5 & SB \\
\hline & b. Komunikatif & 84.5 & SB \\
\hline & c. Dialogis dan interaktif & 80.0 & $\mathrm{~B}$ \\
\hline & d. Kesesuaian dengan tingkat perkembangan belajar & 80.5 & $\mathrm{~B}$ \\
\hline & e. Keruntutan dan ketepatan alur pikir & 80.5 & $\mathrm{~B}$ \\
\hline & f. Penggunaan istilah, simbol atau ikon & 80.5 & SB \\
\hline
\end{tabular}

Keterangan: $\mathrm{B}=$ Baik dan SB = Sangat Baik

Tabel 8. Respon Mahasiswa terhadap Modul Perencanaan Pembelajaran Akuntansi

\begin{tabular}{|c|l|c|c|}
\hline No. & \multicolumn{1}{|c|}{ Indikator } & $\%$ & Kriteria \\
\hline 1 & Aspek Tampilan: & & \\
\hline & a. Teks atau tulisan pada modul ini mudah dibaca. & 80.15 & SB \\
\hline & b. Gambar yang disajikan jelas atau tidak buram. & 80.26 & SB \\
\hline & $\begin{array}{l}\text { c. Gambar yang disajikan sudah sesuai (tidak terlalu banyak dan tidak } \\
\text { terlalu sedikit) }\end{array}$ & 88.63 & \\
\hline & $\begin{array}{l}\text { d. Adanya keterangan pada setiap gambar yang disajikan dalam modul } \\
\text { ini. }\end{array}$ & 78.64 & B \\
\hline & e. Gambar yang disajikan menarik. & 68.83 & B \\
\hline
\end{tabular}




\begin{tabular}{|c|c|c|c|}
\hline \multirow[t]{13}{*}{2} & Aspek Penyajian Materi: & & \\
\hline & $\begin{array}{l}\text { a. Modul ini menjelaskan suatu konsep menggunakan ilustrasi masalah } \\
\text { yang berkaitan }\end{array}$ & 75.94 & B \\
\hline & b. Modul ini menggunakan contoh-contoh soal yang berkaitan & 80.15 & SB \\
\hline & $\begin{array}{l}\text { c. Penyajian materi dalam modul ini mendorong saya untuk berdiskusi } \\
\text { dengan teman-teman yang lain. }\end{array}$ & 80.26 & SB \\
\hline & $\begin{array}{l}\text { d. Penyajian materi dalam modul ini berkaitan dengan materi matematika } \\
\text { yang lain atau dengan mata pelajaran yang lain dalam pemecahan } \\
\text { masalah dan penerapannya. }\end{array}$ & 88.63 & SB \\
\hline & e. Saya dapat memahami materi dengan mudah. & 78.64 & SB \\
\hline & f. Materi yang disajikan dalam modul sudah runtut. & & \\
\hline & $\begin{array}{l}\text { g. Saya dapat mengikuti kegiatan belajar tahap demi tahap dengan } \\
\text { mudah. }\end{array}$ & 80.26 & SB \\
\hline & $\begin{array}{l}\text { h. Saya dapat dengan mudah memahami kalimat yang digunakan dalam } \\
\text { modul ini. }\end{array}$ & 88.63 & SB \\
\hline & i. Tidak ada kalimat yang menimbulkan makna ganda dalam modul ini. & 80.26 & $\mathrm{~B}$ \\
\hline & j. Saya dapat memahami pada modul ini. & 88.63 & SB \\
\hline & k. Saya dapat memahami istilah-istilah yang digunakan dalam modul ini. & 78.64 & SB \\
\hline & $\begin{array}{l}\text { 1. Contoh soal yang digunakan dalam modul ini sudah sesuai dengan } \\
\text { materi. }\end{array}$ & 80.26 & SB \\
\hline \multirow[t]{7}{*}{3} & Aspek Manfaat: & & \\
\hline & a. Saya dapat memahami materi menggunakan modul ini dengan mudah & 80.26 & $\mathrm{~B}$ \\
\hline & b. Saya merasa lebih mudah belajar dengan menggunakan modul ini & 88.63 & SB \\
\hline & c. Saya sangat tertarik menggunakan modul ini. & 78.64 & B \\
\hline & d. Dengan menggunakan modul ini saya lebih tertarik dalam belajar. & 80.74 & SB \\
\hline & $\begin{array}{l}\text { e. Dengan adanya ilustrasi disetiap awal materi dapat memberikan } \\
\text { motivasi untuk mempelajari materi. }\end{array}$ & 76.32 & B \\
\hline & f. Saya lebih rajin belajar dengan menggunakan modul ini & 80.23 & SB \\
\hline
\end{tabular}

Keterangan: $\mathrm{B}=$ Baik dan $\mathrm{SB}=$ Sangat Baik

Uji operasional yang dilakukan secara bersiklus melalui empat tahapan utama, yaitu perencanaan, pelaksanaan, observasi, dan refleksi. Uji operasional lebih bersifat perbaikan terhadap model sebelum dilakukan uji eksperimen. Dalam uji operasional ini terdiri dari dua siklus. Dalam setiap siklus terdiri dari tiga tindakan dan satu pertemuan untuk evaluasi. Data pada setiap siklus diambil menggunakan lembar observasi terhadap unjuk kerja dan hasil kerja selama proses pembelajaran. Item penilaian atau pengamatan dikembangkan berdasarkan indikator-indikator dalam menggunakan alat dan bahan.

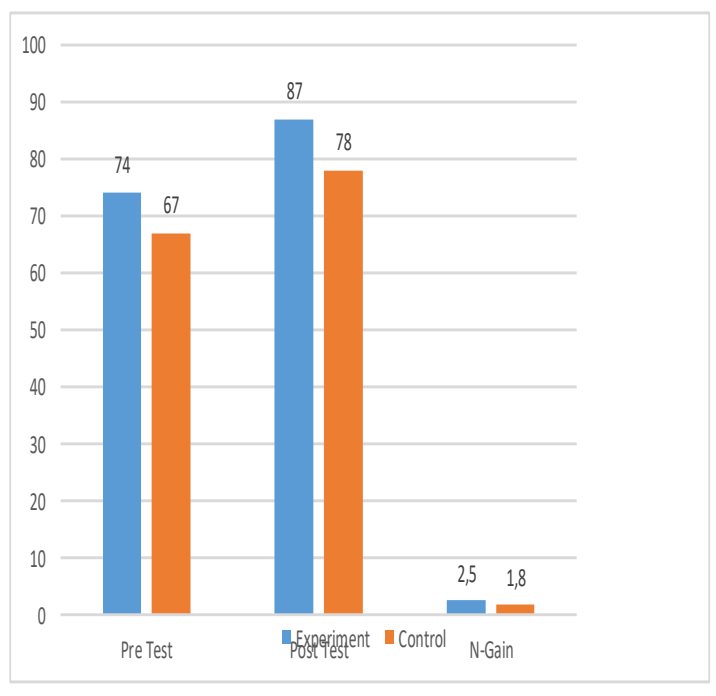

Gambar 1. Perbandingan nilai rata-rata pretes, postes, dan n-gain

Kajian terhadap modul pembelajaran berbasis experiential learning yang dikembangkan, kompetensi dan materi pembelajaran yang telah ditemukan pada tahap pertama. Modul pembelajaran berbasis experiential learning pada mahasiswa dilakukan uji coba dan validasi ahli/pakar di bidangnya. Dengan demikian tahap kedua ini akan dilakukan validasi modul pembelajaran, media pembelajaran, dan uji coba modul serta media pembelajaran pada perencanaan pembelajaran akuntansi.

Penelitian diharapkan akan dapat menghasilkan dan mengembangkan modul pembelajaran berbasis experiential learning. modul pembelajaran berbasis experiential learning mampu memberikan pola strategi pembelajaran yang berbeda sesuai dengan tingkat dan perkembangan kognitif mahasiswa, serta penggunaan teknologi yang menyertai dalam proses pembelajaran berlangsung. Kemampuan ditekankan pada kemampuan 
tingkat tinggi, yaitu pada C4 sampai dengan C6 sesuai dengan kemampuan kognitif mahasiswa dalam upaya meningkatkan penguasaan terhadap matakuliah perencanaan pembelajaran akuntansi. Melalui serangkaian tahap pengembangan dan validasi ahli serta uji coba pada tahap II akan dapat menghasilkan modul pembelajaran berbasis experiential learning yang dapat digunakan dalam pengembangan proses pembelajaran dengan baik pada mahasiswa.

Uji coba modul pembelajaran berbasis experiential learning dilakukan dalam tahap kedua ini melalui uji coba perseorangan, uji coba kelompok kecil, dan uji coba lapangan dengan beberapa mahasiswa, disamping itu juga dilakukan uji ahli terhadap bidang studi, ahli rancangan pembelajaran. Dari hasil uji coba diharapkan diperoleh masukan sebagai bahan penyempurnaan draft modul yang diuji cobakan. Hasil kajian pada tahap kedua ini adalah desain modul pembelajaran berbasis experiential learning pada mahasiswa. Hasil uji coba dan validasi dari ahli untuk selanjutnya dilakukan revisi pada masing-masing aspek dan komponen modul pembelajaran berbasis experiential learning untuk penyempurnaan modul pembelajaran yang dikembangkan. Pada tahap ke dua ini juga dilakukan uji coba melalui: review ahli bidang studi, review ahli design pembelajaran, uji coba perorangan, uji coba kelompok kecil, dan uji coba lapangan/utama.

Hasil uji coba dan validasi dari ahli untuk selanjutnya dilakukan revisi pada masing-masing aspek dan komponen modul pembelajaran berbasis experiential learning untuk penyempurnaan modul pembelajaran yang dikembangkan.

Perencanaa pembelajaran dan pengembangan merupakan matakuliah bidang pendidikan di jurusan pendidikan akuntansi dan merupakan salah satu wujud dari pembentukan komunitas belajar yang harus di kuasai bagi pengajar/dosen dalam pelaksanaan pembelajaran. Terbentuknya komunitas belajar merupakan sarana untuk pengembangan diri setiap guru. modul pembelajaran berbasis experiential learning akan meningkatkan rasa kebersamaan dan kolegialitas antara sesama mahasiswa calon guru dalam mempraktekkan dengan menggunakan karakter sebagai bagian penanaman dalam pembelajaran dan aspek konstruktivistik selalu ditekankan kepada mahasiswa agar dapat mengembangkan dan mengngonstruk pengetahuan dan wawasannya untuk lebih baik lagi. .

Pelaksanaan pembelajaran dengan menerapkan modul pembelajaran berbasis experiential learning diharapkan setiap mahasiswa siap untuk mengubah mindset seperti yang sudah dilaksanakan oleh penulis dalam rangka untuk mendapat gagasan yang berharga dalam proses pembelajaran. Dosen atau Guru sebagai ujung tombak pendidikan diharapkan lebih bersifat terbuka, mau menerima perubahan apapun dalam dunia pendidikan dengan berupaya memperbaiki pembelajaran yang telah dilakukan dalam perencanaan pembelajaran akuntansi.

Implementasi modul pembelajaran berbasis experiential learning secara berkelanjutan akan membantu mahasiswa calon guru mempercepat peningkatan profesionalismenya. Indikator-indikator peningkatan melalui implementasi, adalah pengembangan rancangan dan pelaksanaan semester (RPS) yang selalu menuntut dilakukannya inovasi pembelajaran dan asesmen, yang memungkinkan mahasiswa untuk dapat mengembangkan pemikiran kritis dan kreatif tentang belajar dan pembelajaran, proses sharing pengalaman berbasis pengamatan pembelajaran memberi peluang bagi dosen untuk mengembangkan keterbukaan dan peningkatan kompetensi sosialnya, dan proses-proses refleksi secara berkelanjutan adalah suatu ajang bagi dosen untuk meningkatkan kesadaran akan keterbatasan dirinya.

Perencanaan pembelajaran dan pengembangan merupakan mata kuliah di bidang pendidikan pada jurusan pendidikan akuntansi dan merupakan salah satu bentuk pembentukan komunitas belajar yang harus dikuasai guru / dosen dalam melaksanakan pembelajaran. Melalui penerapan modul pembelajaran berbasis experiential learning merupakan sarana untuk pengembangan diri setiap guru. Pembelajaran akan meningkatkan rasa kebersamaan dan kekompakan antar mahasiswa calon guru dalam prakteknya dengan menggunakan karakter sebagai bagian dari penanaman dalam pembelajaran dan aspek konstruktivis selalu ditekankan kepada mahasiswa agar dapat mengembangkan dan mengngonstruk ilmu dan wawasannya menjadi lebih baik lagi.

Hasil penelitian yang didukung oleh Suciati, Ibrahim, R. Delfi, S. Julaeha (2007) 
menyatakan bahwa pembelajaran melalui pengalaman menekankan pada hubungan yang harmonis antara kegiatan belajar-kerja-hidup dengan penciptaan pengetahuan itu sendiri. Agar mahasiswa dapat belajar, guru bertugas mengkondisikan kelas dan lingkungan yang menyenangkan, membantu mahasiswa mengatasi kecemasan, membantu mahasiswa mengenali perbedaan situasi sehingga dapat melakukan generalisasi (Baharuddin dan Wahyuni (2007). Joni dan Wardani (2000) menyebutkan ciri-ciri dasar belajar melalui pengalaman, yaitu (1) dipersepsikan sebagai proses daripada hasil, (2) proses berkelanjutan melalui pengalaman, (3) proses pembelajaran adalah penyelesaian konflik dialektis antar dasar. lawan cara beradaptasi dengan lingkungan, (4) adalah proses adaptasi holistik ke dunia luar, (5) adalah interaksi antara individu dan lingkungan, dan (6) adalah proses menciptakan pengetahuan.

Pelaksanaan pembelajaran dengan menerapkan modul pembelajaran berbasis experiential learning ini diharapkan mahasiswa siap mengubah pola pikir seperti yang telah dilakukan penulis agar mendapatkan ide-ide yang berharga dalam proses pembelajaran. Dosen atau guru sebagai ujung tombak pendidikan diharapkan lebih terbuka, mau menerima setiap perubahan dunia pendidikan dengan berusaha meningkatkan pembelajaran yang selama ini dilakukan dalam perencanaan pembelajaran akuntansi.

Penerapan modul pembelajaran berbasis experiential learning akan membantu calon mahasiswa calon guru mempercepat pengembangan profesionalnya. Indikator peningkatan melalui implementasi adalah perkembangan desain dan implementasi semester (RPS) yang selalu menuntut inovasi dan penilaian pembelajaran, yang memungkinkan mahasiswa mengembangkan pemikiran kritis dan kreatif tentang pembelajaran dan pembelajaran, proses berbagi pengalaman berdasarkan observasi pembelajaran memberikan peluang bagi Dosen mengembangkan keterbukaan dan meningkatkan kompetensi sosialnya, serta proses refleksi secara berkelanjutan merupakan ajang bagi dosen untuk menumbuhkan kesadaran akan keterbatasannya.

\section{PENUTUP}

Ahli Desain Pembelajaran, ahli konten materi, dan ahli desain grafis dalam pengembangan modul pembelajaran berbasis experiential learning menyatakan layak untuk digunakan dalam perencanaan pembelajaran akuntansi. Respon mahasiswa terhadap modul Perencanaan dan Pembelajaran layak digunakan dalam proses pembelajaran pada mata kuliah perencanaan pembelajaran akuntansi, karena aspek pengembangan modul sudah mencakup keseluruhan komponen dalam modul untuk pembelajaran.

Kualitas pelaksanaan pembelajaran pada uji coba terbatas sangat baik dan layak digunakan dalam proses pembelajaran perencanaan pembelajaran akuntansi. Penilaian Mahasiswa terhadap Pelaksanaan Pembelajaran menggunakan buku ajar melalui Uji Coba Terbatas layak digunakan dalam proses perencanaan pembelajaran akuntansi.

Rata-rata hasil belajar perencanaan pembelajaran pendidikan akuntasi mahasiswa menunjukkan bahwa ada perbedaan yang signifikasi, bahwa yang dibelajarkan dengan menggunakan modul Pembelajaran berbasis Eksperimen Kolb lebih tinggi pada hasil pretes, postes dari pada dengan konvensional. Hal ini menunjukkan bahwa modul pembelajaran yang dikembangkan mampu meningkatkan hasil belajar mahasiswa dalam pembelajaran perencanaan pembelajaran akuntansi.

\section{DAFTAR PUSTAKA}

Baharuddin \& Esa Nur Wahyuni. (2007). Teori Belajar \& Pembelajaran. Yogyakarta: Ar-Ruzz Media

Baharuddin and Wahyuni, E.N. (2007). Teori Belajar \& Pembelajaran. Yogyakarta: ArRuzz Media, 2007

Joyce, Bruce, Marsha Weil, \& Emily Calhoun.(2000). Models of Teaching. USA: Library of Congress Cataloging-inPublication Data

Kolb, A. dan Kolb DA. (2001). Experiential Learning Theory Bibliography 19712001, Boston, Ma : McBer and Co, http://trgmcber.haygroup.com/Products/1 earning/bibliography.htm

Kolb, AY, \& Kolb, DA (2005). Inventarisasi Gaya Belajar Kolb - Versi 3.1: 2005 Spesifikasi Teknis. Haygroup: Pengalaman Berdasarkan Learning Systems Inc.

Kolb, DA (1976) Inventarisasi Gaya Belajar: Manual Teknis, Boston, Ma .: McBer.

Kolb, DA (1981) 'Gaya belajar dan perbedaan disiplin'. dalam AW Chickering (ed.) 
Modern American College, San Muhammad. (2015). Model-Model Francisco: Jossey-Bass. Pembelajaran Inovatif. Yogyakarta: Ar-

Kolb, DA (dengan J. Osland dan I. Rubin) (1995a). Eksperimental Perilaku Organisasi: Pendekatanuntuk Perilaku Manusia dalam Organisasi 6e, Englewood Cliffs, NJ: Prentice Hall.

Kolb, DA (dengan J. Osland dan I. Rubin) (1995b) Pembaca Perilaku Organisasi 6e, Englewood Cliffs, NJ: Prentice Hall.

Kolb, David A. (1984). Experiential Learning: Experience as The Source of Learning and Development. Englewood Cliffs: Prentice Hall Pembelajaran Inovatif. Yogyakarta: Ar-
Ruzz Media Sardiman A. M. (2004). Interaksi dan Motivasi Belajar Mengajar. Jakarta: Raja Grafindo Persada.

Schroeder, Nicholas W., Previous Accounting Education and College-Level Accounting Exam Performance, Issues in Accounting Education, Vol.1 No.1.

Subiyanto, Ibnu. (1993), Metode Penelitian Akuntansi, Edisi kedua, Cetakan Pertama, Bagian Penerbitan STIE YKPN, Yogyakarta.

Kolb, David A., Irwin M. Rubin, Joyce Osland. (1991). Organizational Behavior: An Experiental Approach. Englewood Cliffs: Prentice Hall

Kolb. DA and Fry, R. (1975) 'Menuju teori penerapan pengalaman belajar ; dalam C. Cooper (ed.) Teori Proses Kelompok, London: John Wiley.

Manolas, E.I. (2005), “Kolb's Experiential Learning Model: Enlivening Physics Courses in Primary Education". The Internet TESL Journal. 3,(9).

Suciati, Ibrahim, R. Delfi, S. Julaeha. (2007). Belajar Pembelajaran. Jakarta: Penerbit Universitas Terbuka, 2007

Suciati, Ibrahim, Refni Delfi, Siti Julaeha. (2007). Belajar Pembelajaran. Jakarta: Penerbit Universitas Terbuka

Trianto. (2014) . Mendesain Model Pembelajaran Unofatif-Progresif Konsep, Landasan Dan Implementasinya Pada Kurikulum Tingkat Satuan Pendidikan (KTSP). Jakarta: Kencana Media Group 